\title{
Problems Redesigning University EFL Curricula: A Case Study
}

\section{Giancarla Unser-Schutz \\ Rissho University}

\section{Reference Data}

Unser-Schutz, G. (2021). Problems redesigning university EFL curricula: A case study. In P. Clements, R. Derrah, \& P. Ferguson (Eds.), Communities of teachers \& learners. JALT. https://doi. org/10.37546/JALTPCP2020-03

As English education programs mature, it is common for them to need to adjust their curricula. Adapting in a timely manner can be an especially acute problem at universities, which are under Adapting in a timely manner can be an especially acute problem at universities, which are under
pressure to respond to changes in education policies while also following regulations to maintain accreditation as degree-granting institutions. To observe how these issues affect redesigning curricula, this article undertakes a case study of one faculty currently in the midst of change. The faculty went through two major periods of changes, but as will be observed, the timing and success of these changes has been swayed by major practical and procedural issues, including restrictions on curriculum changes for accreditation purposes, changes in the labor laws, budgetary restrictions limiting hiring, and changes in university admissions examinations. The discussion considers how these issues were approached while offering observations about how best practices in curriculum design can be implemented effectively given institutional restrictions. 英語教育プログラムの成長に伴いカリキュラム改正が必要になることが多い。日々変わる教育政策に対応しながら認可 にかかわる規則を篇守することが求められる大学においては、カリキュラム改正はことに困難である。いかなる問題が発生す るのかを究明するため、本稿では英語教育のカリキュラム改正に取り組んでいる学部の事例研究を試みる。当該学部は 2 期 に渡ってカリキュラム改正に取り組んできたが、改正の時期と効果は、大学認可のためのカリキュラム改正の規制、学働法の つつ、カリキュラム改正の計画と実施をするための工夫の仕方を提示する。

hanges in English education curricula can become necessary for a variety of reasons. Requiring compliance with policies to maintain licensing and funding can be compelling for many institutions, and unanticipated implementation issues may be discovered after curricula are in place. English language teaching (ELT) is also subject to trends, and new directions in ELT best practices may lead to gaps between curricula in situ and what teachers and students desire. However, redesigning a program's curriculum can be daunting given the complexity of the process. It can be especially difficult at universities in Japan, where there is strong pressure to respond to changes in education policies by the Ministry of Education (MEXT) (Goldfinch, 2006). At the same time, restrictions in how promptly changes can be implemented can lead to situations where curricula in situ quickly go out of sync with what is desired on the ground.

Assessing how these issues play out could indicate better practices for the planning and implementation of curricula. The current paper starts that process by examining the development of the English as a foreign language (EFL) curriculum at the author's faculty over time as a case study. The author's faculty has gone through two periods of change within a relatively short period of time, the first of which was originally reported in Unser-Schutz (2016). This study focuses on the following questions through a comparison of the circumstances of these two periods of change: What motivated the faculty to implement changes in the curriculum? What institutional and procedural barriers towards their implementation are identifiable? By addressing these questions, the paper furthers understanding how different forces affect new curricula, especially in Japanese universities.

\section{Case-Study Overview}

The faculty in question is the faculty of psychology at a mid-tier private university in the Tokyo area. As of April 2021, the university is made up of nine faculties, of which psychology has been generally ranked the highest (Benesse Corporation, 2018). The second youngest faculty in the university, the faculty of psychology was established in 2002. It is currently comprised of two departments: The department of clinical psychology (CP; 170 students), originally the only department in the faculty, and the 
department of interpersonal and social psychology (ISP; 115 students), established in 2011. Now approaching the faculty's $20^{\text {th }}$ anniversary, the faculty is not as young as it had been at the time of the original case study discussed in Unser-Schutz (2016); nonetheless, it is still relatively young within the institution as a whole, which dates back to 1872 .

The faculty typically accepts few international and adult students each year, and the majority of students are accepted straight out of high school. Approximately half of all students are admitted through recommendation - that is, they were recommended by their high schools and evaluated primarily on their grades, supporting documents and interviews, rather than their scores on a competitive academic entrance examination. This is relevant to ELT because it has been shown that there are distinct differences in Japanese students' English ability by how they gained admittance to university. Students who gained admittance through recommendation tend to be less confident about and proficient in English than those who gained admittance through the competitive academic entrance examinations, even after matriculating and studying at the university level (Unser-Schutz, 2020). Such tendencies suggest that students' English language ability may not be consistent across the student body, which would influence how an effective curriculum might function.

\section{Two Periods of Change in the Faculty's English Education}

The faculty has gone through two major periods of curriculum change over time. From its inception in 2002 until 2015, the faculty's English classes remained largely untouched. The original curriculum consisted of three required English classes: English 1 and English 2, first year reading and writing courses, respectively, and English 3, a second year speaking course. It also offered a limited number of elective courses. Starting in 2013, the faculty began the initial process of review, leading to the implementation of a new curriculum in 2015. The second period of change is still ongoing, and was first initiated in 2019 with the goal of implementing a fully overhauled curriculum in 2022-later than the original goal of 2021 due to the Covid-19 global health crisis.

\section{Initial Changes: 2013 to 2015}

Although talks to revise the curriculum began in 2013, they did not actually come to fruition until 2015. The timing of these changes coincided with the maturation of the department of ISP. The accreditation of new universities as well as faculties and departments therein require strict reporting and compliance with the initially approved curriculum until their kansei-nendo 'year of completion', that is, when the first matriculated class graduates (Shioya, 2014). The year of completion was 2014, making 2015 the first year it was possible to change the EFL curriculum. Overviewed in UnserSchutz (2016), the initial round of changes was motivated by students' consistently poor review of the faculty's EFL courses in comparison with other subject courses: In a survey given to current students on the different courses in the faculty, students reported being $20 \%$ less satisfied with English classes than they were with other general education courses, and $40 \%$ less satisfied than they were with the faculty's psychology subject courses. The faculty valued these evaluations as significant issues in part because of the increasing importance of third-party evaluations from 2002 onwards (Kitamura, 2003), which also means an increase in required internal evaluation reports. Consequently, the goals of these original plans were to revise the faculty's EFL curriculum to improve the quality of classes and to improve student satisfaction, and thereby indirectly improve the faculty's evaluations on outside reports.

The need to change the EFL curriculum was first brought up as an issue in the faculty's curriculum committee, which meets several times a month to discuss, review and make any plans regarding the implementation and development of curriculum within the faculty. The two full-time teachers-one from each department, one Japanese and one non-Japanese-who are members of the curriculum committee were entrusted by the committee to undertake the task of proposing how to improve the curriculum. Reviewing student surveys, discussions with teachers and an analysis of the thencurrent curriculum, it became clear that there was a lack of clear vision for the faculty's EFL program. Although there were three required classes, there were no curriculum documents at the time outlining what each class was supposed to do: The different sections of each class were connected only by their common titles. Teachers were allowed to select their own texts and write their own syllabi, which offered them a large degree of freedom.

In this sense, the EFL curriculum was less centrally managed than the psychology content courses, even in comparison with similarly required subject courses that also had multiple sections such as the required first year seminar, which utilized a common syllabus. Given the sheer number of EFL courses and the number of teachers needed to cover them in the faculty - at the time of writing the original case study, there were 18 teachers ( 3 full-time, 15 part-time) for 40 courses-diversity between sections was inevitable without such guidelines. Yet, while individual teachers were allowed to have great autonomy over their classes, students were assigned which sections they were to take by the faculty. Consequently, there was great variation between classes based upon individual teaching styles and materials, but no locus of control for students. It is 
easy to imagine that this would lead to student dissatisfaction, and indeed, the lack of consistency across course sections was frequently mentioned in student surveys.

To address these problems, the faculty sought to clarify the role of EFL in three ways. The first way was to create curriculum guidelines for the courses, which would clarify the contents and connections between them. Since no prior documents existed for EFL at the time, these were developed through discussions between the full-time English instructors, through evaluating the current classes and their contents, as well as through examining the programs at other universities. The guidelines focused on the course contents and goals of each class, which are both required components of the university syllabi, thus facilitating a smooth connection between the guidelines and the course syllabi. Attention was also paid to noting how each course was meant to connect to each other, so that students would have a clearer idea of how their English studies at the faculty were meant to advance over time. To further increase the transparency of the courses, the titles of the required classes were changed so that they better reflected their contents: English 1 was renamed English Reading, English 2 became English Writing, and English 3 became English Speaking.

The actual curriculum documents-translated from the original Japanese-can be found in Appendix, Table 1. It should be noted that the changes to the courses were primarily made within the structural limitations of the original curriculum. This was done for two reasons. First, the negative student evaluations primarily focused on the lack of consistency between course sections, rather than the contents of the courses themselves. Second, larger-scale changes-such as creating original materials, adding classes, or holding faculty development sessions-would have required an established budget line, which was not available at the time. Consequently, the major themes and the number of required classes were largely left intact. After the guidelines were developed, the original proposal was presented at the curriculum committee, to receive feedback from non-EFL staff. The finalized guidelines were ratified and shared at a subsequent faculty meeting, and have since been introduced to new students every year at freshman guidance.

The second way was to utilize a common textbook and syllabus for the required courses. By requiring that teachers use a set textbook with a syllabus clearly outlining how grades would be evaluated, it was expected that classes would become consistent across sections of the same courses. Since this was the major complaint students reported, the use of common course materials was seen as essential for improving the curriculum. The syllabi themselves were written with the new guidelines in mind, and in addition to outlining the contents and goals of each course, also detailed the semester- long plan for each class meeting, and a breakdown of how grades are to be calculated. Finally, the third way was to begin dedicated EFL surveys on students' evaluations of their studies and interest in English, given to students at the beginning of their first and second years, and at the end of their second year, as they progressed through the required English courses. This was done in order to track how these changes played out over time, as well as to see how students' interest in English changes as they progress through the program.

By implementing these changes, the faculty sought to increase consistency between classes-both through the use of common materials and the establishment of common goals through the curriculum guides-and to enable appropriate follow up in the future. Reviewing the changes' impact, it can be said that they were successful in so far as the adoption of common syllabi and textbooks for required courses led to outward consistency. However, it became apparent that these changes were not sufficient on their own. The surveys conducted after the faculty began to follow the new curriculum indicated that there was not a vast improvement of students' interest in English study overtime. Many students also continued to note their frustration with discrepancies between classes. Although the faculty sought to improve consistency across sections by holding several information sessions prior to introducing the curriculum, the goal of those sessions was to introduce the new textbook, rather than formalized training. Budgetary limitations meant that information sessions could not be conducted regularly afterwards, meaning that the faculty did not closely manage how the materials were subsequently used in the classroom. Consequently, although the classes now looked the same outwardly, in reality, the adoption of a required common textbook and syllabus failed to ensure cohesion between classes on its own, at least as far as students' perceptions were concerned. Aside from these issues, the surveys also indicated issues with the contents of the courses. Although English classes comprise a good percentage of all required classes, they also continued to be isolated from the rest of the subject classes in so far as they did not touch upon psychology or any of the themes of the other subject classes. Some students also expressed dissatisfaction with this in the surveys.

\section{Second Changes: 2019 to Present}

In comparison to the original round of changes, a major impetus behind the second round of changes currently being undertaken since 2019 was changes in the Japanese examination system, originally planned to take effect in 2020 by MEXT. A critical component of this was the move to accept third-party English examinations such as TOEIC in lieu of the traditional English examinations administered by universities, 
with particular emphasis on such examinations' ability to test students' comprehensive proficiency over 4-ginō 'four skills' (reading, writing, listening and speaking). Although temporarily on hold, there is no reason to believe that MEXT intends to change directions, effectively completing the policy shift towards communicative approaches in Japanese English education initiated over 20 years ago (Kubota, 1998). Although responses differ at individual high schools (Nakamura, Maeda, \& Sato, 2020), these changes will affect how students are taught and what they expect at university. It makes sense that universities would respond by adjusting their EFL programs (Mizuhara, 2019) suggesting that the faculty's reaction is consistent with current trends.

Several different strategies were adopted in order to ensure that the second round of changes led to the development of a more effective curriculum. Most crucially, in comparison with the original changes - which were primarily planned by the full-time EFL faculty members-an important characteristic of these second changes is that they are being formed by a working group (WG) of EFL and non-EFL faculty members. Collaboration with non-EFL faculty members was considered vital as a major goal was to establish a clearer vision for faculty that was consistent with the $3 P s-$ i.e., the admissions, curriculum, and diploma policies. Consistency with these policies is increasingly impactful on how universities are evaluated by MEXT (Tanabe, 2019), especially in the years following the original changes. While redesigning the curriculum, the WG closely examined the faculty documents on the 3Ps, reexamining how the faculty described its goals for English language education and internationalism, leading to the development of the classes outlined in Appendix, Table 2. Note that at present, the WG is focusing on the required classes only. In order to focus the faculty's efforts on the most essential classes first, there are no immediate plans to change the elective courses in Appendix, Table 1.

Given the emphasis on developing comprehensive communication and interpersonal skills outlined in the 3Ps, the WG determined that the new English classes should be task-based and focus on the comprehensive development of communicative skills, rather than focus specifically on which of the four skills they strengthened. Task-based teaching was considered advantageous for the reasons outlined by Ellis (2009, p. 242), including that it was conducive to classroom-based natural learning and developing communicative fluency. An added advantage was perceived to be that it would give tangible common tasks for teachers to assign that they could also adapt as necessary. The first year Strategic English has been particularly designed around task-based teaching, with the goal of developing students' confidence through naturalistic tasks for different communicative settings that would assist them as they move through the program, such as developing strategies for asking about and describing unfamiliar words. The WG is currently working on developing the materials and tasks for the new classes. These materials will be used when establishing common goal-keeping for the different sections through shared online portfolios, assignments and examinations, and will contribute to consistency throughout the course sections.

To increase the relevance of English classes for students, the WG also decided to incorporate psychology themes and develop connections with subject courses to scaffold students' learning. In the newly designed first year English for Presentations course, students will be asked to present on topics also covered in their Japanese-language presentation and freshman seminar courses. The WG is also collaborating with faculty members to create texts for the second year Academic English for Psychology based upon core themes of required courses. In addition to conforming with long-standing trends towards content-based instruction (Butler, 2005), the WG also aimed to support students wishing to enter graduate school, a common goal for psychology students aiming for specialized qualifications. This usually requires taking English entrance examinations, most commonly translating English language psychology texts.

\section{Potential Issues and Solutions}

Reviewing the first research question, it is clear that there were both internal and external pressures motivating the faculty to implement changes in the curriculum, in both the first and second round of changes. The internal pressure largely took the form of negative student evaluations of the curriculum. As the major recipients of curricula, students' responses are clearly vital. Effectively responding to students' voices is likely a common challenge in revising curricula. Externally, shifts in government policies also played a major part. In the first round of changes, rising dependence on external evaluations was particularly important. In comparison, MEXT's increased focus on university educational policies and changes in university entrance examinations played a greater role in the second round. Looking at the second question, however, there were also clear institutional and procedural barriers limiting the effectiveness of the changes. For the first round in particular, budgetary issues often played an oversized role in determining what changes would occur, and staffing issues-primarily in the form of a dependence on part-time staff and a lack of continued communication about how the curriculum should be-also limited the effectiveness of the new curriculum

It cannot be said how these issues will play out in the current round of changes. However, the planned changes are at a greater scale, and thus more challenging, then 
those of the first round. Due to how situational circumstances surrounding the original round of changes, the changes introduced in 2015 were largely piecemeal, in so far as they involved primarily making changes around the current curriculum (maintaining the same number of classes per first and second year students, keeping the themes of the courses largely consistent with their pre-change topics). Small or moderate changes are often preferred due to their ease of implementation, and because they require less administrative overview to complete, including fewer adjustments in the faculty budget, school rules and policies: See, for example, Horiuchi's (2020) analysis of the distinct preference of Japanese universities to start English-language degree programs by 'addingon' programs to extant faculties.

However, as in the case study outlined here, such incremental changes may not actually fulfill the needs they are meant to fill. Such piecemeal changes do not appear to affect change amongst staff, who may not recognize the differences between the prior and current curricula. Securing success for the new round of changes is a multi-pronged task, which requires passing first through several administrative hurdles. After the initial proposal and syllabi were formulated, gaining approval for the new curriculum required going through the departmental faculty meetings, the faculty curriculum committee,and finally, the overall faculty meeting. The next step in the process is to revise the faculty regulations, which is now planned for the spring of 2021, and the WG is presently creating materials and working out the fine details for 2022. Additional work, however, will be necessary to ensure the new curriculum's success.

As was clear from the initial 2015 changes, gaining the cooperation and understanding of the teaching staff is essential to the new curriculum's implementation. Using the same materials alone does not result in consistency across sections because teachers may interpret how the materials are to be used differently, and individual teaching styles will also differ. Closer follow-up on teachers' use of the materials and their compliance with common syllabi will be necessary for the new curriculum to function effectively. The faculty aims to address this through using online portfolios. However, doing so requires finding balance between individual teachers' educational principles and the needs of the faculty vis-a-vis common goal-setting. In particular, limiting teachers' abilities to make decisions for their classes could lead to dissatisfaction. Involving all teachers and making sure their opinions are heard will be a vital component of implementing the new curriculum, which will require continued and better faculty training and development. The issues that remained after the original round of changes led to greater understanding of the need to use more faculty discretionary funding for the EFL program, which has made it possible for the WG to plan four training and information sessions to be held in the 2021 school year to introduce teachers to the new curriculum, receive feedback, and conduct training for the materials. Regular faculty development meetings are also being planned for after the new curriculum is implemented.

Faculty training also ties into hiring issues. Although hiring more full-time teachers would increase cohesion, this would require establishing a permanent and hefty budget line, which-for better or worse-goes against the trend to use more adjunct teachers for language teaching (Katsuki, 2018), and it is unlikely that this will change in the near future. Yet, not all current adjunct teachers on staff may feel initially comfortable with the new classes, which will not only be more restrictive in terms of their content, but also use very different materials with very different learning goals. At the same time, changes in the labor laws and the enactment of the so-called 5 -year rule allowing contract staff to apply for their position to become permanent after 5 years ( 10 years for universities: Carlet, 2017) mean that current staff must be prioritized in hiring for the new courses. As the faculty will primarily be working with the current staff, leading them through the process will also be an important part of faculty support. Training will most likely be especially required for less technologically savvy staff given the use of online portfolios. The often ad hoc response to online teaching following the global health crisis of 2020 has especially made this clear and put the lack of cohesion between teachers in EFL classes into relief.

These issues clearly also indicate the need for a greater administrative role for full-time staff, a trend common within Japanese education (Mizumoto, 2017). Taking on a greater administrative role introduces new questions that will need to be addressed over time. For example, how many courses are appropriate for the full-time staff to teach while also taking on the burden of creating materials and overseeing the adjunct staff? Should full-time EFL staff focus exclusively on the EFL classes, or should they continue to have other roles in the faculty such as teaching the freshman, junior and senior seminars? Negotiating the roles of full-time staff will be a continuing issue as the new curriculum rolls out.

\section{Conclusions}

Although the current paper only follows one case study, the issues that the faculty has faced are likely not unique. Generalizing from this case study, several forces influencing the successful implementation of new curricula can be identified, including reporting requirements limiting the timing of school regulations, changes in admissions examinations, the restrictions of current labor laws, and expectations for the roles that 
full-time and part-time faculty members should play. How successful newly adapted EFL curricula will be appears to be highly dependent on securing the support of adjunct teachers, establishing clear goals, and having full-time staff take on a more administrative role in order to follow through by further developing positive relationships across the staff and making sure that those goals are being met. Whether the new curriculum will be successful will have to be readdressed in follow up research now being planned, but the faculty is hopeful that they will be successful given the development of a larger vision for the EFL program and greater faculty support.

\section{Bio Data}

Giancarla Unser-Schutz is an associate professor at Rissho University. She is currently interested in how to improve motivation and interest amongst students in nonEFL-specialist faculties. She also conducts research outside of EFL on the linguistic characteristics of manga as well as Japanese naming practices. Her publications may be found at http://rissho.academia.edu/GiancarlaUnserschutz/.<giancarlaunserschutz@ris. ac.jp>

\section{References}

Benesse Corporation. (2018, October 22). 立正大学 / 偏差值 [Rissho University /Deviation scores]. Benesse マナビジョン [Benesse Manavision]. Retrieved October 22, 2018, from https://manabi. benesse.ne.jp/daigaku/school/3323/index.html

Butler, Y. G. (2005). Content-based instruction in EFL contexts: Considerations for effective implementation. JALT Journal, 27(2), 227-245. https://doi.org/10.37546/JALT]J27.2-5

Carlet, L. (2017, July 30). Are university teachers in Japan covered by the 'five-year' rule? Japan Times. http://www.japantimes.co.j/ommunit/01///ssue/niversity-teachers-japan-covered-fiveyear-rule

Ellis, R. (2009). Task-based learning teaching: Sorting out the misunderstandings. International Journal of Applied Linguistics, 19(3), 221-246. https://doi.org/10.1111/j.1473-4192.2009.00231.x

Goldfinch, S. (2006). Rituals of reform, policy transfer, and the National University Corporation reforms of Japan. Governance: An International Journal of Policy, Administration, and Institutions, 19(4), 585-604. https://doi.org/10.1111/j.1468-0491.2006.00341.x
Horiuchi, K. (2020). 学士課程における英語プログラムの組織モデルの類型化と日本的特性--同型化理 論から見る学部併設型」集中傾向の外部環境要因 利用統計を見る [Typification of institutional model and isomorphic pattern of English-taught programs in Japan : Exploring external factors for predominance of “faculty add-on" model]. 北九州市立大学国際論集 [University of Kitakyushu International Papers], (18), 29-42. Retrieved from https://kitakyu.repo.nii. ac.jp/?action=repository_uri\&item_id=763\&file_id=22\&file_no=1

Katsuki, Y. (2018). 日本語教師はごのような感情地勢の中で実践を行っているか一大学で教える非常勤講 師の語りの分析 - [The emotional geography of Japanese language teacher practice: An analysis of narratives from part-time university instructors]. 神戸学院大学グローバル・コミュニケーション 学会紀要 [Kobe Gakuin University Journal of Global Communication Studies], 3, 33-47. http://doi. org/10.32129/00000061

Kitamura, K. (2003). 日本における大学評価政策の形成と立法過程 [A third party evaluation policy and legislating process in Japanese higher education]. 教育社会学研究 Journal of Educational Sociology], 72, 53-71. https://doi.org/10.11151/eds1951.72.53

Kubota, R. (1998). Ideologies of English in Japan. World Englishes, 17(3), 295-306. https://doi. org/10.1111/1467-971X.00105

Mizuhara, K. (2019). 2020年大学入試改革に向けた大学及び高等学校の動向分析:多面的·総合的な 評価を中心に [Trend analysis of high school education and exam changes of each universities in the process to university entrance exam reform in 2020: Focusing on a multipronged, comprehensive evaluation]. 尚絧学院大学紀要 [Shokei Gakuin University Departmental Bulletin], (78), 1-17. Retrieved from https://shokei.repo.nii.ac.jp/?action=repository_uri\&item_ id=446\&file_id=21\&file_no $=1$

Mizumoto, T. (2017). 学習観の転換と経営管理主義の行方:公教育経営における権力様式に関する言 語行為論的検討 [Transformation of the theory of learning and the future of managerialism: Investigation of forms of power in public educational administration from the perspective of speech act theory]. 教育学研究 [Japanese Journal of Educational Research], 84(4), 398-409. https:// doi.org/10.11555/kyoiku.84.4_398

Nakamura, K., Maeda, K. \& Sato, E. (2020). 大学入試に求ける共通試駼改革が高校の教育課程や進学指 導に与える影響をめぐる一考察: 首都圈の高校へのインタビュー調查を踏まえて [How does the reform of the university entrance examination affect the high schools' curricula and counseling for the choice of a university?: From the interviews with high school teachers in the metropolitan area] 東京大学大学院教育学研究科教育行政学論丵 [The Journal of Educational Administration Graduate School of Education, the University of Tokyo], 40, 89-98. Retrieved from https://repository.dl.itc.utokyo.ac.jp/index.php?active_action=repository_view_main_item_detail\&page_id=28\&block_ id $=31 \&$ item $\_$id $=54611$ \&item $\_$no $=1$ 


\section{JALT2020}

COMMUNITIES OF
TEACHERS \& IEARNERS
Shioya, H. (2014). 日本の行政過程の特色--大学設置認可過程(平成24年)を素材として [Characteristic of administrative process of Japan--an example of the 2012 process of chartering of universities]. 日本學士院紀要 [Proceedings of the Japan Academy], 68(2), 113-137. https://doi.org/10.2183/ tja.68.2_113

Tanabe, M. (2019). 学士課程教育の三つのポリシーとアウトカム基盤型教育 [Three policies in the baccalaureate degree program and outcome-based education]. 医学教育 [ournal of the Japanese Society for Medical Education], 48(4), 237-242. https://doi.org/10.11307/mededjapan.48.4_237

Unser-Schutz, G. (2016). Improving a university English program: Issues from one case study. In P. Clements, A. Krause, \& H. Brown (Eds.), Focus on the learner (pp. 14-21). Tokyo: JALT. Retrieved from http://jalt-publications.org/sites/default/files/pdf-article/jalt2015-pcp_003.pdf

Unser-Schutz, G. (2020). What do entrance examinations say about EFL outcomes at universities? In C. Peter, A. Krause, \& R. Gentry (Eds.), Teacher efficacy, learner agency (pp. 568-578). Tokyo: JALT. https://doi.org/10.37546/JALTPCP2019-64

\section{Appendix}

Table 1

Revised Curriculum Implemented in 2015 (Adapted from Unser-Schutz 2016)

\begin{tabular}{|c|c|c|c|c|c|}
\hline Type & Class & $\begin{array}{l}\text { CP or } \\
\text { ISP? }\end{array}$ & Year & Contents & Goals \\
\hline $\mathrm{R}$ & $\begin{array}{l}\text { English } \\
\text { Reading I/II }\end{array}$ & $\begin{array}{l}\mathrm{CP} / \\
\mathrm{ISP}\end{array}$ & 1 & $\begin{array}{l}\text { Students review } \\
\text { grammar forms learned } \\
\text { prior to university; } \\
\text { read newspapers and } \\
\text { magazine articles and } \\
\text { study naturalistic } \\
\text { forms and vocabulary } \\
\text { featured using a } \\
\text { required textbook }\end{array}$ & $\begin{array}{l}\text { Improve basic } \\
\text { grammatical forms } \\
\text { and vocabulary; } \\
\text { train for second year } \\
\text { speaking course; be } \\
\text { able to quickly read } \\
\text { and understand } 3 \sim 4 \\
\text { paragraph newspaper } \\
\text { articles and article } \\
\text { excerpts. }\end{array}$ \\
\hline
\end{tabular}

\begin{tabular}{|c|c|c|c|c|c|}
\hline Type & Class & $\begin{array}{l}\text { CP or } \\
\text { ISP? }\end{array}$ & Year & Contents & Goals \\
\hline $\mathrm{R}$ & $\begin{array}{l}\text { English } \\
\text { Writing I/II }\end{array}$ & $\begin{array}{l}\mathrm{CP} / \\
\mathrm{ISP}\end{array}$ & 1 & $\begin{array}{l}\text { Students review } \\
\text { grammar forms learned } \\
\text { prior to university; } \\
\text { practice writing about } \\
\text { different themes from a } \\
\text { required textbook. }\end{array}$ & $\begin{array}{l}\text { Improve basic } \\
\text { grammatical forms } \\
\text { and vocabulary; } \\
\text { train for second year } \\
\text { speaking course; be } \\
\text { able to effectively write } \\
\text { opinions and thoughts } \\
\text { about reading materials }\end{array}$ \\
\hline $\mathrm{R}$ & $\begin{array}{l}\text { English } \\
\text { Speaking } \\
\text { I/ll }\end{array}$ & $\begin{array}{l}\text { CP / } \\
\text { ISP }\end{array}$ & 2 & $\begin{array}{l}\text { Students practice } \\
\text { practical everyday oral } \\
\text { expressions while using } \\
\text { grammatical forms and } \\
\text { vocabulary studied in } \\
\text { the first year using a } \\
\text { required textbook. }\end{array}$ & $\begin{array}{l}\text { Acquire the speaking } \\
\text { skills necessary } \\
\text { to conduct basic } \\
\text { conversation while } \\
\text { studying abroad or } \\
\text { conducting work post- } \\
\text { graduation; learn how } \\
\text { to effectively express } \\
\text { thoughts and will. }\end{array}$ \\
\hline $\mathrm{E}$ & $\begin{array}{l}\text { Advanced } \\
\text { English: } \\
\text { TOEIC I/II }\end{array}$ & $\begin{array}{l}\mathrm{CP} / \\
\mathrm{ISP}\end{array}$ & $2 \sim$ & $\begin{array}{l}\text { Students strategically } \\
\text { study the listening and } \\
\text { reading skills required } \\
\text { for the TOEIC exam }\end{array}$ & $\begin{array}{l}\text { Improve TOEIC scores } \\
\text { and strategic test taking } \\
\text { skills }\end{array}$ \\
\hline $\mathrm{E}$ & $\begin{array}{l}\text { Advanced } \\
\text { English: } \\
\text { Academic } \\
\text { Reading I/Il }\end{array}$ & $\begin{array}{l}\mathrm{CP} / \\
\mathrm{ISP}\end{array}$ & $2 \sim$ & $\begin{array}{l}\text { Students practice } \\
\text { skimming and } \\
\text { summarizing academic } \\
\text { texts; study translation } \\
\text { strategies. }\end{array}$ & $\begin{array}{l}\text { Acquire basic skills } \\
\text { necessary for reading } \\
\text { academic psychological } \\
\text { texts. }\end{array}$ \\
\hline
\end{tabular}


Type Class

CP or
ISP?
CP

E Reading

English

Materials

I/II

E English

Psychology

Readings

E

Practical

English

[Skype] I/II

$\mathrm{CP}$

2 Following Advanced

English: Academic

Reading, students will continue to learn how

to summarize, skim

and translate academic

texts.

Students converse Improve their practical online with students in English communication the Philippines about everyday topics.

skills by participating

in conversation

with fluent speakers

in naturalistic

conversation.
F Study

Abroad

CP

Training

\section{Students who did}

independent short-

term study abroad can

apply for credit to be
Encourage and

recognize students

who have conducted independent study.
Notes. Type refers to the type of course, specifically: $R=$ Required, courses which students must pass in order to graduate; $E=$ Elective, courses which students may take, and whose credit counts towards their general education credits for graduation; $F=$ Free, courses for which students can receive credit, but which do not count towards graduation. I refers to a class taught in the first semester; Il to a class taught in the second semester. $C P$ refers to the department of clinical psychology; ISP to the department of interpersonal and social psychology.
Table 2

The Revised Curriculum to be Implemented in 2022 (Required Courses Only; Both Faculties)

\begin{tabular}{|c|c|c|c|c|}
\hline Class & Year & Semester & Contents & Goals \\
\hline Strategic English & 1 & 1 & $\begin{array}{l}\text { Students will study } \\
\text { strategies helpful in } \\
\text { different situations; } \\
\text { review themes and } \\
\text { expressions from } \\
\text { English for Everyday } \\
\text { Psychology }\end{array}$ & $\begin{array}{l}\text { Be able to use } \\
\text { effective English } \\
\text { in different } \\
\text { communicative } \\
\text { situations; develop } \\
\text { interest/confidence in } \\
\text { English }\end{array}$ \\
\hline $\begin{array}{l}\text { English for } \\
\text { Everyday } \\
\text { Psychology }\end{array}$ & 1 & 1 & $\begin{array}{l}\text { Students will practice } \\
\text { using English } \\
\text { comprehensively } \\
\text { while studying } \\
\text { about everyday } \\
\text { psychological } \\
\text { phenomena }\end{array}$ & $\begin{array}{l}\text { Be able to talk } \\
\text { about everyday } \\
\text { psychological } \\
\text { phenomena; establish } \\
\text { base skills for more } \\
\text { advanced study }\end{array}$ \\
\hline $\begin{array}{l}\text { Communicative } \\
\text { English }\end{array}$ & 1 & 2 & $\begin{array}{l}\text { Students will learn } \\
\text { differences in written } \\
\text { and spoken language } \\
\text { using everyday } \\
\text { themes; themes } \\
\text { linked to English for } \\
\text { Presentations }\end{array}$ & $\begin{array}{l}\text { Be able to talk/ } \\
\text { write about } \\
\text { everyday themes } \\
\text { and psychological } \\
\text { phenomena; } \\
\text { be conscious of } \\
\text { differences in } \\
\text { modality }\end{array}$ \\
\hline $\begin{array}{l}\text { English for } \\
\text { Presentations }\end{array}$ & 1 & 2 & $\begin{array}{l}\text { Students will practice } \\
\text { using English for } \\
\text { presentations; } \\
\text { themes linked to } \\
\text { presentations in } \\
\text { subject courses }\end{array}$ & $\begin{array}{l}\text { Be able to use } \\
\text { persuasive language } \\
\text { and state opinions } \\
\text { about issues }\end{array}$ \\
\hline
\end{tabular}




\section{JALT2020}

COMMUNITIES OF
TEACHERS \& LEARNERS

\begin{tabular}{lccll}
\hline Class & Year & Semester & \multicolumn{1}{c}{ Contents } & \multicolumn{1}{c}{ Goals } \\
\hline $\begin{array}{l}\text { Academic English } \\
\text { for Psychology I/ll }\end{array}$ & 2 & $1 / 2$ & $\begin{array}{l}\text { Students will read } \\
\text { more advanced } \\
\text { psychology texts } \\
\text { and practice talking } \\
\text { about them in applied } \\
\text { situations }\end{array}$ & $\begin{array}{l}\text { Better understand } \\
\text { and talk about } \\
\text { everyday } \\
\text { psychological } \\
\text { phenomena; develop } \\
\text { academic English } \\
\text { skills }\end{array}$ \\
\hline
\end{tabular}

Notes. I refers to a class taught in the first semester; Il to a class taught in the second semester. 